\title{
Oyster mushroom-A viable indigenous food source for rural
} masses

Varsha Satankar, V. Mageshwaran, P. Jagajanantha and Khursheed Alam Khan

Received : 10.04.2018; Accepted : 13.04.2018

See end of the Paper for authors' affiliation

Correspondence to :

\section{Varsha Satankar}

Ginning Training Center, ICAR-Central Institute for Research on Cotton Technology, Nagpur (M.S.) India

Email : satankarvarsha@gmail. $\underline{\text { com }}$
- Abstract : Oyster mushroom cultivation is an economically viable process for conversion of various ligno-cellulosic wastes into valuable food. It can be artificially cultivated on various agroresidues, viz., cotton stalks, wheat and rice straw etc. The yield of mushroom varies with the substrate used and it may be around $500 \mathrm{~g} / \mathrm{kg}$ of raw material.Mushrooms are highly nutritious, environment friendly crops and have numerous benefits. They are a very good source of protein, vitamins and minerals. But the cultivation and adoption of oyster mushroom in India is very limited compare to other crop. This may be due to lack of awareness and appreciation as a food source, monotonous traditional diets and the conservative eating habit of people. The present workaimed to study onvarious oyster mushroom cultivation techniques, their storage and processing methods and substrates used in the production of Pleurotus spp., for oyster mushroom cultivation. Experiments were conducted at GTC, ICAR-CIRCOT, Nagpur for cultivation of oyster mushroom (Pleurotus florida and Pleurotus ostreatus) using cotton stalks. The results showed $300 \mathrm{~g}$ of fresh oyster mushroom could harvest from one $\mathrm{kg}$ of dry cotton stalks. The cropping period for cultivation of oyster mushroom in cotton stalks was thirty days.The implication of this study is to facilitate technology adoption of oyster mushroom cultivation using cotton stalks and thereby identify the feasibility of mushroom cultivation in the study area for the betterment of the life of the local community.

- Key words : Oyster mushroom, Rural masses, Spawn quality

- How to cite this paper : Satankar, Varsha, Mageshwaran, V., Jagajanantha, P. and Khan, Khursheed Alam (2018). Oyster mushroom-A viable indigenous food source for rural masses. Internat. J. Agric. Engg., 11(Sp. Issue) : 173-178, DOI: 10.15740/HAS/IJAE/11.Sp. Issue/173-178. 